\title{
The Good, the Bad, and the Ugly: Lessons from the 103rd and 104th Congresses, and What We May Expect in the 107th
}

By Aaron A. Otto

\begin{abstract}
The congressional elections of 1994 gave the GOP a unique opportunity: the chance to govern as the majority party in the House for the first time in 40 years. However, the balance of power in the House has narrowed with every election cycle since 1994, giving the Democrats the potential to retake the majority in 2000. Although either party may be in a position to serve in the majority, the more likely scenario is that both parties will probably be at parity with each other. This article compares the management styles and priorities of the last Democratic Congress (103rd, 1993-95) with the subsequent Republican Congress $(104 t h, 1995-97)$ to discover which lessons can be learned about how, given the opportunity, either party would manage the House in the upcoming 107th Congress. This article will also review some of the transitional difficulties that took place the last time control of the House changed between the two parties in 1995.
\end{abstract}

\section{Introduction}

Adjusting to the rules and internal affairs of Congress is no simple task. It can seem almost daunting when a party moves from minority to majority status as occurred in 1995 when the Republicans outnumbered the Democrats in Congress. Considering the obstacles and complexity involved in drafting and passing legislation combined with the challenges of maintaining party unity by balancing interests and personalities, the Republicans adjusted well to their new position as the majority party. However, this transition did not come easily. The Republicans failed to pass their programs and lost the occasional public relations struggle. However, for the first year of the 104th Congress (1995-97), the Republicans exhibited extremely strong party unity and were success-

Aaron A. Otto is currently a Presidential Management Intern serving as a Policy Analyst for the U.S. Department of the Navy. While earning a Master of Public Administration degree from the George Washington University, Otto also served as co-president of the Master of Public Administration Association and was a member of the American Society for Public Administration. Prior to attending $G W$, Otto earned a bachelor degree in political science from Kansas State University with minors in business administration and leadership studies. ful in passing their party's agenda.

One of the most useful performance indicators of the 104th Congressional Republican leadership is its ability to retain the majority in future elections. During the 1996 congressional elections, the Republicans maintained back-to-back control of the House for the first time in sixty-two years. This was a minor success. Even though they remained in the majority, the GOP lost seats. The situation was repeated in the 1998 elections when the House Republican presence shrunk to a mere six-seat majority in a 435-person chamber. Both the 1996 and 1998 losses left the GOP with one of the smallest majorities since 1954, the last Republican majority before the 1990s. The Republicans must avoid repeating the 1996 and 1998 election results during the 2000 congressional elections, when they will be forced to defend three times as many open seats as their Democratic counterparts. Open seats traditionally have a higher probability of turnover, changing from one party's control to another rather than an incumbent going down to defeat by the other party's challenger.

With the balance of numbers and power between the two parties nearly the same heading into the November 2000 elections, the stakes are high and the implications are potent. After November 8,2000 the majority party will be able to direct the organization and structure of the House. To discover clues as to how the two parties would likely manage the House one, only needs to look back to the differences between the Democratically-controlled 103rd Congress and the 104th Republican Congress. Although there was only a two-year difference 
between the two parties' control of the House, the GOP leadership under Speaker Newt Gingrich significantly altered the operational structure of the House. Yet because the Republicans had not held the majority since 1954 -in fact, none of the 230 House Republicans had ever served in the majority party- the transition from the opposition party to the governing party was not without problems.

This article will focus on the structural changes introduced by the Republican led 103rd Congress, highlight the significant differences between the management and organization styles of the respective parties, and discuss the success and failures of the Republican reform efforts.

\section{The 1994 Congressional Election}

On November 8, 1994, an event took place that many Americans had never seen. For the first time in forty years and for only the third time since 1932, the Republican Party won a majority of seats in the United States House of Representatives. At the time, some political scientists and reporters predicted the Senate would suffer enough turnovers in membership to give control to the Republicans, but almost no one, including most Republicans, could have predicted the incredible turn around in number of House seats. In short, the Republican Party in the House had effectively hammered away at the Democratic majority for six years under the leadership of their minority whip Newt Gingrich of Georgia, and their efforts had finally paid off.

In 1994, Gingrich and other conservative Republicans took advantage of the retirement of long-serving Minority Leader Representative Bob Michel, R-Illinois, and implemented an aggressive campaign strategy and platform entitled "Contract with America." Michel's leadership style had always emphasized compromise over confrontation. With Michel out of the picture for the first time in 12 years, Gingrich used polling and political strat- egy to develop a platform that could be supported by almost every Republican candidate running for the House. His polling indicated that each of the individual planks in the "Contract" was supported by over $80 \%$ of the voting public. The concept of one centralized campaign platform that attempted to nationalize the congressional elections ran against the traditional wisdom of the longest serving Speaker of the House, 'Tip O'Neil, D-Massachusetts, who stated, "all politics is local." I Ignoring O'Neil's famous philosophy, Gingrich took a major political risk and his gamble paid off. Gingrich made it clear that the Republicans only promised a vote on the "Contract" items and there was no guarantee of passage under the Republicans. This clarification allowed his party an excuse if not all of the items in the "Contract" passed under their watch. Two of the primary reasons for the Republicans' dramatic gains in Congress were a strong distrust of Democratic President Bill Clinton and an emergent anti-establishment mood among the electorate against the federal government.

From the 103rd to the 104th Congress, the partisan breakdown in the House of Representatives changed from 256 Democrats, 187 Republicans, and one Independent, to 230 Republicans, 204 Democrats, and one Independent. Despite this 52-seat shift, the Republican majority was one of the five smallest majorities this century. ${ }^{2}$ Nonetheless, Republicans were able to develop and maintain a high degree of party unity, which translated into a solid voting block for Republican proposals. The high degree of Republican party discipline owed its existence in no small part to the experience of having been shut out of power for the previous forty years. But the unusual degree of party discipline was not unique to the Republicans, for the Democrats also exhibited a similar behavior. A significant contributing factor towards the emergence of strong party loyalty within both parties of the 104th Congress was the dufut of many moderate 
southern Democrats in the 1994 Congressional elections These erstwhile Democratic seats went to conservative Republicans and, except for a few notable exceptions, left a more homogeneous liberal northern and West Coast based Democratic minority. ${ }^{3}$ The resulting polarization caused a greater imbalance within the political spectrum, which had shifted from one characterized by a broad representation of political interests during the 103rd Congress to one typified by the more stridently ideological positions of the 104th Congress. Because of the strong ideological dichotomy formed by the far extremes of the two parties, the floor votes of the 104th Congress were marked by very few defections in either party.

\section{Republicans institute organizational reform and build a stronger power structure}

The Republicans continued institutional reform in the House of Representatives and built a stronger power structure than the Democratic majority during the104th Congress. One of the major 1994 campaign promises of the new Republican majority had been to reform the House of Representatives at all levels. This reform package took many shapes including: eliminating several subcommittees and standing committees; reducing congressional staff sizes; changing the manner in which committee chairs are appointed, banning proxy votes in committees, provide for more open rules in committees, opening up committee meetings to the public aning media, and undertaking committee staff hiring reform. Republicans did not support these reforms alone; newly elected members of Congress, both Republicans and Democrats, favored them. With over half of the membership of House elected after 1990, this cross-party majority was more inclined to support popular reform ideas. "The 220 House members elected since the turn of the decade was part of a new mindset that focused on instructional reform and modernizing management practices.
House Resolution 1 required Congress to follow the same laws that apply to the rest of the country. For example, Congress would now be required to follow the 1964 Civil Rights Act, the 1990 Americans with Disabilities Act, and the 1993 Family and Medical Leave Act. The House passed a rule that implemented an outside audit of Congress to reduce and eliminate fraud and abuse. Republicans also cut individual personal Congressional staffs by one-third to surpass the one-fourth reduction in White House staff implemented two years earlier. ${ }^{5}$

The GOP also required all committee meetings be open to the public. ${ }^{6}$ This was a major change from the past. Previous congressional practices accepted some closed meetings as the norm. In addition, Republicans required votes and verbatim transcripts of hearings and meetings to be published in committee reports. ${ }^{7}$ This was not an entirely new step as the Democrats had begun to open up the committee process during their last two years in the majority, 1993-95. The Democratic leadership had changed the rules regarding discharge petitions from committees by allowing the signers names to be made public. As was the case with reducing the number of overall committees, the Democrats started to make the changes and the Republicans expedited them.

Another area of reform for House Republicans was to foster more open debate of legislation before the full House. The GOP felt severely mistreated when it was in the minority because majority Democrats would put closed rules on many of the major pieces of legislation, thereby barring Republican efforts to amend legislation on the floor. At the same time, several Republican members feared the promise to allow open rules would hamper their efforts to pass the items in the "Contract" during the first 100 days of 104th Congressional session. Speaker Gingrich was convinced that the ideas contained in the "Contract" would receive such wide support from the public that it would provide the necessary momen- 
tum to pass all of the promises into law before their selfimposed 100-day deadline for action and results. ${ }^{8}$

One of the first major decisions the Republicans faced as part of their reform package before they officially took power in the House was how to downsize the number of subcommittees and standing committees. To accomplish this, they targeted committees that traditionally had represented a Democratic constituency base, such as the District of Columbia Standing Committee, which traditionally has been an overwhelmingly Democratic municipality. As a result, the Republicans reduced the number of standing committees from 22 to 19 . In addition to the District of Columbia Committee, the committees the Merchant Marine and Fisheries, and Post Office and Civil Service Committees were disolved. The duties and jurisdictions of the eliminated committees were reassigned to other committees. A fourth specialized committee, the House Small Business Committee, was also scheduled to be eliminated and its functions rolled into the Commerce Committee. However, after intense lobbying by Representative Jan Meyers, R-Kansas, and several other key Republicans, the Committee was preserved. These lawmakers believed it would be a mistake to do away with a committee that represents a key constituency group, one that is extremely loyal to the Republican Party. Also, after making most of the committee chair appointments, Speaker Gingrich realized that Meyers would be one of only two females to chair a standing committee. He did not want to risk alienating female Republican voters. Thereby he agreed to maintain the committee and named Meyers as the chair. ${ }^{9}$

The Republicans also eliminated over thirty subcommittees. These changes greatly reduced the number of overall committee assignments available for House members. In addition, the House Republican Conference, made up of GOP House members, completely eliminated funding and staff for congressional policy groups and caucuses such as the Congressional Black Caucus. The primary reason for the elimination of these groups was to save money, but Republicans also believed that these groups were left-leaning due to the Democratic Party's long control of staff hiring.

The Republicans have taken much public credit for reducing the number of committees and shrinking the size of the legislative branch. However, the reform efforts to reduce the number of congressional subcommittees and overall staff size began long before the Republicans took control of Congress. The Republican Party's goal to reduce the number of congressional committees was simply an expedited version of efforts already being made by their Democratic predecessors. Since 1984, Democrats reduced the number of subcommittees from a high of 142 to 115 in 1994 . They also reduced the number of select and special committees from 6 in 1986 to 1 in 1994. With the reduction of select committees came the reduction of subcommittees for select committees from 12 in 1984 to 3 in 1994. Finally, the Democrats reduced the number of subcommittees of joint House and Senate committees from 8 in 1986 to zero in $1994 .^{10}$

The Republicans continued on a fast-paced schedule to reduce the number of committees and staffs and to reform congressional procedures. It seems logical that if the Democrats regain the majority, they would return the rules and procedures used by Democratic majorities for the last forty years. However, this is still up for debate. In 1996, Representative Paul Kanjorski, D-Pennsylvania, said "We won't reconstitute either the D.C. or the Postal committees when we win again. We may strive for better committee alignment with the executive branch. But I didn't mind seeing some change. Even some of the name (changes) of committees was useful (for modernization purposes)." But other senior Democrats had a slightly different take than Kanjorski. Rep- 
resentative Ben Cardin, D-Maryland, head of the Democratic transition team in 1995, said that Republicans missed a historic opportunity to effect more change. "They catered to special interests. The structural changes they made were all partisan and designed to their advantage," Cardin said. The Democratic leadership echoed this opinion during the first 100 days. ${ }^{11}$

Another area of reform for Congressional Republicans was the use of proxy voting in committee. Many Republicans believed Democrats historically abused this privilege, so they eliminated the practice. While in the majority, Democratic committee chairs used large blocks of Democratic proxy votes to ensure a win despite having fewer members in actual attendance at the committee meeting. For example, a committee might have a total membership of 15 and eight members decide to attend. Seven of the members at the meeting are Republicans and the other one is the Democratic chair. When votes on Republican amendments or ideas would come before Democratically controlled committees, they would still lose despite the votes of those members in attendance. In this case, the Republicans would vote for a GOP amendment and the Democratic chair would use the majority Democratic proxies to defeat the idea. Following the elimination of proxy voting, the Democrats complained however their minority status made resurrecting the rule impossible.

Consistent with one of the major themes in the "Contract," House Republicans placed term limits on individuals including the Speaker and standing and subcommittee chairs. The Democrats had no term limits for any of these positions and were heavily criticized for the long tenure of several of their committee chairs. Now, a Republican speaker can serve no more than eight years and committee chairs can serve up to six years.

\section{Control over committee chairs and}

\section{sub-committees agendas}

Speaker Gingrich exercised more legislative control over committee chairs and the committee agendas than his Democratic predecessors. Under his leadership, the Republican Revolution centralized power and promoted party unity by changing several rules and procedures for committees.

During the Democratic majority, the Steering and Policy Committee had strong control over the selection of committee chairs. In the 104th Congress, majority party leaders, especially the Speaker, dominated the selection of committee chairs. ${ }^{12}$

Gingrich appointed committee chairs regardless of seniority. He selected individuals for their aggressive conservative leanings and loyalty to him. In some cases he went four or five persons deep into the Republican ranks of the committee to find the soldiers that were dedicated to the "Contract." ${ }^{13}$ Under the Democratic majority, from 1955-1995, committee chairs were sometimes considered mavericks because of their strong sense of independence, which came from the inherent power of a committee chair position and their tenure in a chairperson's office. The Republican Conference voted to reverse many of the Democratic procedures and powers of the committee chairs and thereby removed a great deal of independence from the chairs. Gingrich also unilaterally appointed the GOP chair and committee members of the important House Oversight Committee, under the Democrats this function was perfomed by the Democratic Policy and Steering Committee. ${ }^{14}$

Under the GOP House rules, the committee chairs hired the staff for both standing committees and subcommittees. ${ }^{15}$ The decision about who was going to be hiring the political positions, which are a major source of patronage for supporters, caused a great deal of friction on committee staff between GOP committee chairs and 
GOP subcommittee chairs. Under the Democrats, each committee and subcommittee chair hired their own staff. Under the Republican's rules the standing committee chair had the centralized power to hire all of the committee and subcommittees staff, thereby removing some of the independence of the sub-committee chairs.

In selecting both the committee and subcommittee staffs, the Republican committee chairs were given additional power, which in turn enhanced the power of the Speaker. The Speaker's power increased because, as noted, above the committee chairs lacked independence and the Speaker had the ability to call in favors and maintained an overall umbrella of control. This increased power for committee chairs came from the repeal of the subcommittee bill of rights, enacted by congressional Democrats in the 1970s. By eliminating this concept, committee chairs and the party leadership now had the power to control committee and subcommittee resources. Democrats deplored this centralization of power, but most Republicans, considering their small overall majority in the House in 1995, accepted this change as part of an overall plan to maintain Republican Party unity. ${ }^{16}$ The GOP was only minimally successful in the next election. Although it still maintains a slim majority, each congressional election since 1994 has eroded its status.

Many committee chairs received a wake-up call in 1995 when the Senate Appropriations Chair Mark Hatfield, R-Oregon, became the only Republican to vote against the Balanced Budget Amendment. It failed the Senate by only one vote. In response, many conservative senators wanted to strip the long serving Hatfield of his chairmanship. He maintained his chair position until his retirement only a year later, but this action on the part of rank-in-file members made it clear to committee chairs that their positions were contingent on their support for party policy. ${ }^{17}$

Gingrich also had a unique appointment opportunity outside the traditional Democratic structure in appointing the chair of the Republican Congressional Campaign Committee, which gave him a great deal of influence with many newly elected House Republicans. ${ }^{28}$ The chair of this committee determines where party resources will be used in upcoming elections and thereby can easily reward or punish those who do not support party ideology.

Speaker Gingrich established many party task forces to research and draft legislation on specific issues. He used these task forces, composed completely of House Republicans, to bypass committee chairs, the regular partisan House standing committees, and pursue a centralized, more conservative party agenda. Democrats also used task forces during their previous two decades in power, but their primary intent was to build party support for legislation within their own caucus.

When it came to setting the full House's agenda, Speaker Gingrich and Majority Leader Dick Armey, RTexas, carefully laid out the schedule for passing the "Contract with America" within their own self-imposed deadline of 100 days. By incorporating the use of task forces, Gingrich sped up the committee process.

\section{Task forces are noted for their efficiency}

Taskforce hearings and mark-up sessions were not as lengthy or as formal as committee hearings, and since they were entirely staffed by Republicans there was little disagreement on details or topics. The simplified structure allowed for each of the ten major pieces of legislation to make it to the House floor during the first 100 days. Additionally, senior committee staffs regularly met and communicated with senior members of the leadership staff. This constant communication to outline legislative and political details was in sharp contrast to the 
loosely coupled or sometimes non-existent relationship between committee and leadership staff under the Democrats. ${ }^{19}$ This lack of coordination made it difficult for the Democrats to express a unified message or strategy on major legislative issues.

\section{Republican priorities}

Although the Republicans did not repeal, as they had promised during the campaign, several major pieces of legislation passed by their Democratic predecessors during the 103rd Congress, the Republicans introduced their own agenda regarding what legislation would be considered by the full House. Despite their pre-election boasts, they were rarely able to reverse legislative policies established by their Democratic predecessors concerning such issues as child care, clean air, sanctions against China, deficit reduction, increasing the minimum wage, campaign finance reform, and high technology. On the other hand, the "Contract with America" detailed issues important to the Republicans, including a balanced budget amendment, the line-item veto, welfare reform, family tax cuts, tax credit for children, United Nations troop restrictions, tax cuts for the elderly, capital gains tax cuts, tort reform, term limits, and congressional reform.

The only major piece of legislation passed by the Democrats in 1994 and revised by the Republican-led congress was the 1994 comprehensive Crime and Community Policing Bill. Republicans, who traditionally are "tough on crime" wanted to reclaim this issue from the Democrats. The Republicans also hoped to strip down the cost of the legislation by implementing block grants and cutting out much of the social program spending. Modifications to the crime bill noywithstanding, Republicans have been long on rhetoric and short on action when reversing or repealing legislation that the GOP perceived as anti-business, such as the Family and Medi- cal Leave Act of 1993, or regulatory legislation such as the Cable Communications Act of 1992.

In addition to failing to repeal major pieces of legislation passed by their Democratic predecessors, some Republican members of Congress have been upset at their party for being unwilling to break from the ways of the previous Democratic Congress. For example, Senator John Ashcroft, R-Missouri, said he was disappointed that spending during the first two years of the Republican controlled congress went up by a rate of 10.4 percent in comparison to only a 9.2 percent increase during the prior two Democratic years. ${ }^{21}$ The primary reason for the lack of GOP action is the fear of touching the third rail of American politics. Many of these same programs House Republicans want to eliminate, enjoy vast support from the public. Therefore, it was extremely difficult to reach any type of consensus within the party for how to proceed on these issues.

\section{Passage of the "Contract with America" during the first 100 days}

Only part of the Contract with America was enacted into law during the first100 days of the 104th Congress. Becuase of their long minority status as opposition party, many Republicans believed they had become generally perceived as the party with a consistently negative message. At least in modern political times, never before had the Republicans attempted to draft and enact a national legislative platform of issues. The "Contract with America" was a campaign platform that almost all GOP congressional candidates, both incumbents and challengers, supported during the 1994 election. During the first few months of the legislative session, except for the term limits issue, the Republicans maintained almost a complete party unity on every piece of the "Contract".

Many parts of the "Contract" passed the House with strong bipartisan support (around two-thirds in favor). 
The relatively non-controversial legislation included: 1) opening day reforms such as cutting committees and staff, a ban on proxy voting, auditing the House's books, congressional accountability, and budget reform; 2) Fiscal Responsibility Act, the Balanced Budget Amendment and the Line Item Veto; 3) Taking Back Our Streets Act, the Victim Restitution Act, Criminal Alien Deportation Act, Effective Death Penalty Act and Exclusionary Rule Reform Act; 4) Job Creation and Wage Enhancement Act, Unfunded Mandate Reform Act, Paperwork Reduction Act, Regulatory Reform and Relief Act and Private Property Protection Act; 5) Common Sense Legal Reform Act, the Securities Litigation Reform Act, and Prod uct Liability and Legal Reform Act; 6) The Senior Citizens Equity Act, the Housing for Older Persons Act; 7) Family Reinforcement Act, and the Family Privacy Protection Act. ${ }^{22}$

The two most controversial measures in the "Contract" were the balanced budget amendment and term limits. During the first few weeks of the Republican Congress, the House Judiciary Committee worked on legislation that would submit a balanced budget amendment to the states for ratification to the Constitution. The Republican proposal would require a three-fifth majority to raise taxes in the future. While in committee the Democrats tried to offer two major amendments: the first would remove the three-fifths requirement for raising taxes; and the second, entitled the Truth In Budgeting Act, would have forced the Republicans to outline the spending cuts needed in order to reach a balanced budget. After nine hours of debate the amendments failed in committee. Republicans passed the bill out of committee on a party line vote over strong objections from Democrats.

Because the GOP wanted to pass some version of the balanced budget amendment the Republican leadership decided to follow a winner-take-all strategy, meaning the competing balanced budget bill that received the most votes would be the version sent onto the Senate for con- sideration. A few days before the bill went before the full House for debate it became very clear that if the Republicans wanted a balanced budget amendment to pass by the required two-thirds margin, they were going to have to compromise on the three-fifths necessary to raise taxes. Speaker Gingrich and Majority Leader Armey realized that the time for compromise had come. The Democratic version of the bill without the three-fifths provision was the only bill that could gain the necessary Democratic support to pass. On the day of the vote, the Republican version of the bill failed to gain the necessary two-third vote and Representative Charles Stenholm, D-Texas, offered the alternative Democratic version. It passed with several dozen votes to spare. Many freshmen Republican members had threatened to vote against any version of the bill except the "Contract" version. However, through personal influence and heavy lobbying by Gingrich and Armey, the new GOP members agreed to compromise rather than risk an outright and absolute defeat of the crown jewel of their platform.

The bill later went over to the Senate and failed on two different occasions to receive the necessary twothirds margin. The first time the bill failed by one vote and the second time it failed by two votes. The battle over this amendment taught the Republicans an important lesson: if they wanted to pass legislation that required 290 votes, two-thirds of the entire House, then they were going to have to be willing to compromise with a significant block of the House Democratic Caucus. Even with the compromise, the amendment failed in the Senate by one vote because the Senate had far fewer newer and conservative Republicans among its ranks.

The second controversial issue was term limits. In the early 1990s, term limits were enacted in several states and many of the new GOP members made it a priority to pass a constitutional amendment enacting term limits on Congressional members. In March 1995 three plans 
were up for debate on the House floor regarding term limits. The 12-12 plan allowed for House and Senate members to serve 12 years in their respective chambers. A 6-12 plan supported by the most conservative Republican members called for service to be limited to six years in the House and twelve years in the Senate. The final plan was the Democratic alternative which enacted the 12-12 plan but made it retroactive thereby forcing many current office holders to retire. Most House members did not view the Democratic alternative as a viable alternative because it was proposed by members who were publicly known for their strong opposition to term limits.

As freshmen Republicans began to build a base of support for the 6-12 plan, the GOP leadership had meetings with key Republicans and specific interests groups. At these meetings, the leadership began to rally behind the 12-12 plan with a federal preemption on state laws. The leadership saw the potential for this plan to gain the most support, especially from Democrats. However, while the Republican leadership focused on the 12-12 plan, special interest groups, including the Christian Coalition, Ross Perot's United We Stand Reform Party, and U.S. Term Limits, began raising support for the rival plan. Open verbal warfare broke out within the Republican ranks in the news media. The leadership supported one bill and the vocal incoming Republican members supported the 6-12 plan. Before the vote in the House, U.S. Term Limits began a massive advertising campaign against Republicans who did not support their version of the bill. When the vote came before the House, the Democratic bill was soundly defeated, and the 6-12 plan received majority support. However, the 6-12 bill fell well short of the two-thirds necessary for passage. The 12-12 plan also fell short of receiving two-thirds approval. After the vote, many newer GOP members were upset with the Republican leadership for their handling of the term limits debate and for not pushing harder for passage of the legislation. In response, Speaker Gingrich expressed his disappointment that the Republicans could not agree internally to support one proposal from the beginning. However he was more upset at U.S. Term Limits for targeting Republican supporters of the 12-12 plan instead of focusing on uncommitted Democrats. ${ }^{23}$

In conclusion, Republicans in the House were fairly successful, especially in the first few months, at passing their party's agenda. This was the time when they believe they completely fulfilled their 100 days campaign promises. During the middle of 1995, public opinion began to shift against the Republicans for not passing all the items within the Contract.

\section{The Republican agenda and the inability to compromise}

Conservative House Republicans simply lacked the ability to compromise with the President and Congressional Democrats to accomplish their goals. During the first 100 days of the Republican Congress, the GOP enjoyed an unprecedented level of party unity and support for general Contract proposals. However, there were a few defeats both legislative and in the realm of public opinion during this time. When the House considered House Resolution 7, some GOP members and congressional watch groups speculated the Republican leadership was getting too comfortable in their positions and taking their members ${ }^{\prime}$ votes for granted. This resolution authorized defense policy and spending for additional research and development of the Star Wars defense program. During debate, the ranking Democrat on the Budget Committee, John Spatt, D-South Carolina, offered an amendment to change defense policy away from national space-based defense to short range weapons. Despite the bill's potential for saving billions of dollars in defense spending, the amendment was not supported 
by the GOP leadership and was expected to fail. However, much to everyone's surprise, the minority's amendment passed. Traditionally these amendment votes are straight-line party decisions because if the majority had wanted an item in a bill, it typically would have been inserted in committee. Therefore, the majority leadership did not endorse any change being made outside of the committee. The amendment brought together Democrats and a group of 25 Republicans, including Budget Chairman John Kasich, R-Ohio, and Banking Chairman Jim Leach, R-Iowa. ${ }^{24}$ This was the first major defeat for the Republican leadership and it taught them another important lesson of not taking Republican votes for granted. In this case, Republicans were torn between reducing spending and increasing the defense budget. If they had done so, they could have quickly found themselves in the same position as their Democratic predecessors with a very divided and undisciplined party.

In addition to a few legislative defeats, the GOP suffered from occasional public relations mistakes during their first 100 days. The debate over the school lunches program is a prime example. Republicans attempted to reduce the cost of this program by giving money to the states to administer it and thereby end direct federal involvement. The Republicans did not propose to cut the program in real dollars. Instead they advocated slowing the rate of growth for the program. The Democrats seized the opportunity to label the GOP plan as cruel to children. They asserted it was unfair to give this money to the states without any way to hold the governors accountable for the funds. Despite the negative the public perception, the GOP was able to hold together in committee. They defeated every Democratic amendment including one to re-title the bill the "Make American Kids Hungry Act." ${ }^{25}$

Another major strategic public relations blunder for the Republicans took place in 1996 when Congress was unable to reach agreement with President Clinton on the FY 1997 federal budget. The resulting stalemate brought about a government shut down. In response to public outcry, the Republican leadership in Congress claimed the President was not willing to compromise and he was the reason the federal government had to be shut down for nearly two months. Unfortunately for Congressional Republicans, the President won the public relations battle on this issue. The President used the White House as a bully pulpit to attack the priorities of House Republicans. He called their platform extreme and cited their inability to compromise as the reason for the shut down. One of the reasons public opinion supported the President's position was because the President, as a singular branch of government, is able to speak with one voice whereas Congress has many individual leaders. Thus, it was simply easier for Clinton to get his message out that he was willing to work with Congress to pass a seven year balanced budget and get the government operating again than it was for the almost $300 \mathrm{GOP}$ members of Congress who said Clinton was unwilling to compromise.

As Gingrich realized the damage that had been done to the Republican Party, he began working with the members of his conference to seek ways to compromise with Clinton. However, the Speaker had a difficult time convincing the members of his own party, especially the freshmen and sophomore members, that compromise was the only option available. This was similar to the problem the GOP leadership faced with the new members over the balanced budget amendment. The new GOP members believed that compromise was exactly what was wrong with politics in Washington. They wanted to wait for the President to concede to their demands for change. After delaying a possible compromise for several weeks, new conservative COP members acquiesed under heavy prestis from the public to 
reopen government services. However, the two government shutdowns diverted public attention away from the Republicans previous legislative victories. In staking out extreme, uncompromising tactics, the GOP handed the President and Congressional Democrats a major public relations victory. One of the reasons why the GOP refused to compromise early in the stalemate was their belief that they would be able to sway public opinion in their favor. However, they learned by experience one of the institutional weaknesses of Congress -the difficulty of putting forth a central unified voice comparable to the singular voice of the President. ${ }^{26}$

\section{Lessons learned from the past: what might change under a possible new Democratic majority in 2001?}

What management styles would House Democrats change if they were returned to power in the November elections? With the relatively tight numbers in the House and the 2000 cycle almost complete at the time of this writing, House Republicans find themselves forced to defend almost three times as many competitive open seat races as their Democratic counterparts. Based on generic congressional party test voting polls observers have predicted that regardless who wins the majority, both parties wil, 1 basically be on an equal footing with each other in regards to overall number of members. In light of the potential change in power, there has been much speculation as to the rules and management structure that would be implemented under the leadership of House Democratic Leader Richard A. Gephardt of Missouri.

Early on many Democrats belittled some of the institutional changes implemented by the Re,publican majority, however now Gephardt appears to be signaling a willingness to embrace many of the Republican institutional reforms. In fact, the possible speaker-to-be said he is willing to maintain the entire package of rule changes implemeted by Republicans in 1995 . The reason for this apparent reversal of beliefs appears to stem from an understanding that whichever party holds the majority in 2001 will be forced to govern with a very small majority as well as from an understanding that the Republican changes brought much needed reforms to the House. The narrow majority creates the possibility that a small handful of members could buck the leadership's direction will demand the use of continued compromise in order to pass basic legislation on a majority vote.

In preparation for their possible takeover after the November election, the Democrats have already begun making transition plans. Remembering the limitations of serving in the minority, the Democrats plan to include broad dispensations to the minority in areas such as scheduling and committee representation. For example, Democratic leaders say they would like to narrow if not completely eliminate the disparity in membership on the House Administration Committee, which is now split 63 despite the close numbers in the House overall. This move would give the minority a greater say and control over the inner workings of the House. ${ }^{27}$ Gephardt spokeswoman Laura Nichols said, "(the leader) wants every decision made in a potential transition to be put through the prism of whether or not it makes the House more a civil institution that respects the views and values of all its members. Mr. Gephardt has made it clear that he has no intention of returning to the old style of management in the House." 28

Perhaps the most interesting part of Gephardt's willingness to adopt the Republican reforms is his acceptance of term limits for committee and subcommittee chairs, which runs directly contrary to the wishes of many senior members of his caucus. Another change instituted by Congressional Republicans was eliminating funding for the Congressional Black Caucus and other Member organizations and doing away with committee 
proxy voting. Both of these issues are expected to be seriously debated if the Democrats take back the House in November. Despite this potential for confrontation, Gephardt believes his position conforms to his message of looking at what works and what does not, and going on from there regardless of who thought of the idea to be "more fair, bipartisan and equitable." ${ }^{29}$

Since 1999, Gephardt has stressed that his party's pursuit of the majority should not be about titles or privileges or retribution for injustices they believed they suffered under the Republican majority..$^{30}$ Representative Cardin, chairman of the party's Organization, Structure and Rules Committee said, "[Congressional Democrats] want to set the temperature at a level where we can get things done in the next Congress." Cardin also said that essentially the Democrats were looking to build a system with majority power and minority privilege. This would include, for example, more amendments under open rules, closing the gap in the ratio between committee Republicans and Democrats to better reflect the makeup of the overall House, and splitting committee resources more equitably. ${ }^{31}$. Finally, Organization Committee member Representative David Minge, D-Minnesota, said Democrats would like the House to remain in session for a longer portion of each week rather than cramming long hours into a few days so that members are able to return to their districts every weekend. ${ }^{32}$

\section{Conclusion}

Even though Gephardt has signaled a willingness to allow most of the Republican institutional reforms to remain, the Democrats will undoubtedly debate some changes in structure if they come to power. And if the Democrats continue to pick up the same number of seats in the 2000 cycle as they did in '96 and '98, then Gephardt will have more than an opportunity to talk about how his party would manage the House. He would rule the chamber as speaker leaving Congressional Republicans in the familiar position of serving in the minority. However, if the GOP is able to maintain its majority in 2001, it will probably do so by a very narrow margin, possibly one of the narrowest in history. Regardless of which party gains the majority, both will operate in relative parity, which will almost certainly force the majority to govern and operate the House in a more bipartisan manner.

\section{NOTES}

'John Barrette, Prairie Politics (Lincoln, NE: Media Publishing and Marketing, 1987) 12.

${ }^{2}$ James A. Thurber and Roger H. Davidson, Remaking Congress: Change and Stability in the 1990s (Washington, DC: Congressional Quarterly Press, 1995) 1.

${ }^{3}$ James G. Gimpel, Legislating the Revolution: The Contract With America In Its First 100 Days (Boston: Allyn \& Bacon, 1996) 13.

${ }^{4}$ Lawrence C. Dodd and Bruce I. Oppenheimer, Congress Reconsidered (Washington, DC: Congressional Quarterly Press, 1997) 23.

${ }^{5}$ Gimpel, 6.

${ }^{6}$ Ibid, 7.

${ }^{7}$ Thurber and Davidson, 33 .

${ }^{8}$ Gimpel, 29.

${ }^{9}$ Norman J. Ornstein, Thomas E. Mann, and Michael J. Malbin, eds. Vital Statistics on Congress 1995-1996 (Washington, DC: Congressional Quarterly Books, 1995), 39.

${ }^{10}$ Ibid, 39.

"I Gimpel, 38.

${ }^{12}$ Thurber, 33.

${ }^{13}$ Gimpel, 36.

${ }^{14}$ Thurber, 5.

${ }^{15}$ Ibid, 33.

${ }^{16}$ Dodd, 40.

${ }^{71}$ lbid, 176.

${ }^{18}$ Thurber, 5. 
${ }^{19}$ Dodd, 177.

${ }^{20}$ Ibid, 349.

${ }^{21}$ Interview with Senator John Ashcroft on C-Span, April 19, 1998.

${ }^{22}$ Gimpel, 132.

${ }^{23}$ Ibid, 103.

${ }^{24}$ Ibid, 76.

${ }^{25}$ Ibid, 87.

26 Dodd, 47.

${ }^{27}$ Ethan Wallison, "Gephardt Embracing Institutional Reforms, Leader Might Back Limits on Panel Chairmen," Roll Call. April 6, 2000: $1-4$.

${ }^{28}$ Ibid, 1.

${ }^{29}$ Ibid, 3.

${ }^{30}$ Ibid, 2

${ }^{31}$ Ibid, 3

${ }^{32}$ Ibid, 4.

\section{REFERENCES}

Ashcroft, Senator John. Interview on C-SPAN. Washington, D.C. April 19, 1998.

Barrette, John. Prairie Politics. Lincoln, Nebraska: Media Publishing and Marketing, 1987.

Dodd, Lawrence C. and Bruce I. Oppenheimer. Congress Reconsidered. Washington, DC: Congressional Quarterly Books, 1997.

Gimpel, James G. Legislating the Revolution: The Contract With America In Its First 100 Days. Boston: Allyn \& Bacon, 1996.

Ornstein, Norman J., Thomas E. Mann, and Michael J. Malbin, eds. Vital Statistics on Congress 1995-1996. Washington DC: Congressional Quarterly Books, 1995.

Thurber, James A. and Roger H. Davidson. Remaking Congress: Change and Stability in the 1990s. Wash ington, DC: Congressional Quarterly Press, 1995.

Wallison, Ethan. "Gephardt Embracing Institutional Reforms, Leader Might Back Limits on Panel Chair men." Roll Call, April 6, 2000. 